\title{
A COMPREHENSIVE TREATMENT FOR GONOCOCCAL AND NON-GONOCOCCAL URETHRITIS*
}

BY

\author{
T. LYALL
}

\section{Liverpool}

Urethritis, either gonococcal or non-specific, is the commonest form of venereal disease. Lees (1951) suggested that of all cases of urethritis probably 50 per cent. are gonococcal, and Harkness (1950) stated that at least 70 per cent. of all his venereal disease patients suffered from non-gonococcal urethritis.

Microscopic examination of smears of the urethral discharge is standard practice in venereal disease clinics before treatment of the condition, but many cases are treated empirically, on the mistaken assumption that all cases of purulent urethral discharge in the male are cases of gonorrhoea. This applies particularly to seamen employed in vessels which do not carry a doctor.

The Penicillin' (Merchant Ships) Act, 1951, so amended the Penicillin Act, 1947, that where a ship does not carry a duly qualified medical practitioner as part of her complement the master, or a person authorized by the master, may administer penicillin subject to the instructions contained in "The Ship Captain's Medical Guide" (Ministry of War Transport, 1946).

Amendment No. 4 of this Guide instructs the master that the urethral discharge of gonorrhoea will be eliminated in 3 to 4 days following a single injection of 200,000 units penicillin in aqueous suspension $(150,000$ units procaine penicillin + 50,000 units crystalline penicillin), that a discharge which persists after such treatment is probably not due to the gonococcus, and that the injection of penicillin must on no account be repeated, a course of sulphathiazole, four tablets thrice daily for 4 days, being advised.

The injunction against the further injection of penicillin is almost invariably ignored where there is a persistent urethral discharge, as is the advice to procure a specimen of the discharge on a glass slide for subsequent examination at a shore clinic. The result is that doses are given of up to 1.2 and 2.0 mega-units of penicillin, with no effect on the persistent urethritis, but perhaps delaying

\footnotetext{
* Received for publication June 23, 1953.
}

for many months the signs of potentially infectious syphilis.

Such misuse of penicillin is not found only where patients have been treated by ships' captains or their deputies; similar cases are frequently referred to venereal disease clinics by medical practitioners after repeated injections of penicillin have failed to eliminate a urethral discharge, which was diagnosed as gonorrhoea on sight with no pathological examination.

In September, 1952, the Editorial of the British Journal of Venereal Diseases was devoted to the question of the treatment of venereal diseases in merchant seamen, and suggested a method of treatment which " would do much to cure urethritis, and yet leave no fear of syphilis d'emblée."

\section{Review of the Literature}

Sulphonamides in Gonorrhoea.-Before the use of penicillin by non-medical persons was authorized in 1951, the treatment for gonorrhoea, recommended in the "Ship Captain's Medical Guide" (1946), was the taking of six $0 \cdot 5-\mathrm{g}$. tablets of sulphathiazole, morning and evening, for 5 days running, together with the ingestion of copious fluids, "Gonorrhoea or Clap" being the name given in this book to all venereal diseases which proclaim themselves by a urethral discharge. This treatment was in line with the "Recommendations of the .Ministry of Health on the Treatment of Merchant Seamen ", issued in March, 1943, but the value of the sulphonamides in the treatment of gonorrhoea had progressively declined since 1939.

At that time, King (1939) claimed over 90 per cent. successes, in nearly 300 cases of gonorrhoea treated with sulphapyridine. Ross (1945), however, obtained only 33 per cent. of successes in 100 consecutive cases of gonorrhoea treated with sulphathiazole, and Dunlop (1949) found only 29 (14.1 per cent.) cured out of 205 males with acute gonorrhoea, who completed 3 months' surveillance after treatment with sulphathiazole. 
Sulphonamides in Non-Specific Urethritis and Urinary Tract Infections.-Nicol (1951) stressed the difficulty of assessing accurately the results of sulphonamide treatment of non-specific urethritis, because of the scarcity of recent publications on the subject, but estimated that probably 50 per cent. of patients treated for urethritis other than gonococcal with sulphonamides alone were either cured or improved.

That sulphonamides were of value in the treatment of such infections was agreed by Harkness (1950), Lees (1950), and King (1950), although their estimations of the value were. couched in vague terms, and appear to differ considerably. For example, Lees thought no improvement was found when cases of abacterial urethritis were treated with sulphonamides, whereas King suggested that sulphonamides were useful in the treatment of this condition.

More recently, Babione and Graham (1952) claimed 90 per cent. success in a series of 1,000 cases of non-specific urethritis treated with sulphadiazine, and concluded that this would be their drug of choice in such infections, chloromycetin, aureomycin, and penicillin, in that order, having proved less effective. The large number of cases studied by these authors appeared to lend particular significance to their conclusions.

Secrétan (1952) stressed the superiority of the sulphonamides over the antibiotics in the treatment of urinary tract infection with Escherichia coli, and placed its effectiveness second only to that of penicillin in Staphylococcus albus infections.

The results of the experiments of Schweinburg and Rutenburg (1949) would lead one to expect such divergences of opinion on the therapeutic value of the sulphonamides. These authors reported that various sulphonamides showed great diversity in their action, not only on different organisms, but also on different strains of the same organism. The organisms used in their experiments were Escherichia coli, Aerobacter aerogenes, Klebsiella pneumoniae, Bacillus proteus vulgaris, and Pseudomonas aeruginosa, all of which have been implicated in infections of the urinary tract.

Of the six sulphonamides used in these experiments, sulphathiazole was found to be effective against a greater number of bacterial strains than any of the others (sulphamethazine, sulphadiazine, sulphamerazine, sulphathalidine, and Gantrisin). The experiments, however, were carried out on only twenty different strains of organism in each case.

Sulphonamide Mixtures.-Combinations of two or more sulphonamides in a single preparation have found favour with a number of clinicians since Lehr (1945 and 1947) demonstrated the increased absorption and higher blood levels of sulphonamide, which could be obtained thereby, along with a reduced tendency to the formation of sulphonamide crystals in the urine. It has since been shown, by Schweinburg and Rutenburg (1950) and Weinstein and Murphy (1952), that, while an additive, or even a synergistic, effect, might be found on using sulphonamide mixtures, the opposite, that is a depression of antibacterial activity, might occur ; the latter authors concluded that the antibacterial effect likely to be produced by mixing sulphonamides was entirely unpredictable.

Dosage of Sulphonamides.-An initial dose of $4.0 \mathrm{~g}$. sulphadiazine, followed by $1 \mathrm{~g}$. every $4 \mathrm{hrs}$, was recommended in the treatment of non-specific urethritis by Babione and Graham (1952). Harkness (1950), having expressed his preference for sulphathiazole or sulphadiazine in the treatment of nongonococcal urinary tract infections, stated that satisfactory results were obtained when they were given in $1 \mathrm{~g}$. doses every $6 \mathrm{hrs}$ for 5 to 10 days.

Personal experience has shown sulphathiazole, in doses of 1 to $1.5 \mathrm{~g}$. 4- to 6-hourly for 5 days together with a generous fluid intake, to be well tolerated by patients, and to produce a high percentage of favourable results.

Streptomycin.-Schatz and others (1944) described an antibiotic substance, which they named streptomycin, and which they had isolated from cultures of an organism related to Actinomyces griseus, after 5 to 12 days' growth. This antibiotic substance they found to be active in vitro, against both Grampositive and Gram-negative bacteria, and to possess only a limited toxicity to animals.

Pulaski (1947) showed that patients given $0.4 \mathrm{~g}$. streptomycin every $4 \mathrm{hrs}$ parenterally excreted more than $1,000 \mu \mathrm{g}$. of the drug per ml. urine in $24 \mathrm{hrs}$, whereas, after oral administration no significant concentration of streptomycin was produced in the urine, and that therefore the parenteral route was the only one likely to be effective in the treatment of infections of the urinary tract.

Keefer and others (1946) had shown that some 60 to 80 per cent. of the drug was excreted in $24 \mathrm{hrs}$ after intramuscular or deep subcutaneous injection, and that a maximum concentration of streptomycin in the blood serum was reached some 1 to $3 \mathrm{hrs}$ after such injection with a following gradual decrease over 10 to $12 \mathrm{hrs}$. They emphasized the ease with which adequate concentrations of 
streptomycin were obtained in the urine for the treatment of infections of the urinary tract.

A number of authors (Kane and Foley, 1947 ; Pool and Cook, 1947 ; Kimmelman and others, 1951) have noted the significant reduction in successful treatments of urinary tract infections, either with streptomycin alone or in combination with other drugs, in cases where any degree of obstruction existed in the urinary tract; and Pulaski (1947) found that complicating prostatitis militated against successful streptomycin therapya result to be expected, since his work on autopsy material had shown no assayable amount of streptomycin in the prostate glands of patients who had been undergoing treatment with the drug.

Combined Streptomycin-Sulphonamide Therapy.Kolmer and Rule (1948) showed evidence, in experimental infections in mice, of a synergistic effect having been obtained by combined streptomycin and sulphonamide therapy. The mice were given an intra-abdominal injection of a suspension of Klebsiella pneumoniae. This was sufficient to kill all ten control mice, but three (30 per cent.) survived of ten mice treated with streptomycin by intermittent intra-abdominal injection to a total of $1.5 \mathrm{mg}$., two (20 per cent.) survived of ten mice given a total of $75 \mathrm{mg}$. sodium sulphadiazine by the same route, and eight ( 80 per cent.) survived of ten mice given both drugs in the same total dose.

That combined therapy gave better results in influenzal meningitis than treatment with one agent alone was the experience of Alexander and others (1946) and Nussbaum and others (1946). Greene and others (1952) reported the additive effect of combining streptomycin and sulphadiazine therapy in the treatment of brucellosis of the urinary tract.

An increase in streptomycin activity against a number of organisms (Strept. pyogenes, Strept. faecalis, Staph. aureus (Oxford strain), B. proteus, $E$. coli, B. typhosus, and Ps. aeruginosa) with increasing $p \mathrm{H}$ (up to $p \mathrm{H} \mathrm{8)}$ was demonstrated by Abraham and Duthie (1946); Eagle and others (1952) observed this increase in activity to be most marked up to $p \mathbf{H} 7 \cdot 3$. Kimmelman and others (1951), using combined streptomycin, penicillin, and sulphonamide therapy in urinary tract infections, claimed equally good results in uncomplicated cases, whether or not the urine had been rendered alkaline, and stated that the addition of alkali had been of no apparent assistance in complicated cases.
Development of Bacterial Resistance to Streptomycin.-The same authors (Kimmelman and others, 1951) reported that while combined therapy did not always prevent the appearance of drug-resistant organisms, the originally sensitive strains had been abolished, and the drug-resistant strains eventually found represented new species. Their further investigations led them to conclude that the intestine was probably the source of the resistant strains found in the urine after treatment. Harris and others (1947) had reported a similar alteration in infecting organisms during treatment. Kimmelman and others also referred to the effect of combined therapy in inhibiting the development of drug resistance in tuberculosis, when streptomycin and PAS or promin therapy have been combined.

Jawetz (1952) suggested that the giving of antibiotics of the bacteriostatic group (aureomycin, chloramphenicol, terramycin), either before or during streptomycin therapy, may reduce the sensitivity of organisms usually sensitive to the bactericidal antibiotics (penicillin, streptomycin, bacitracin, neomycin), and Kaipainen (1951) suggested that organisms exposed to streptomycin develop no cross-resistance to the bacteriostatic antibiotics, and that their sensitivity may well be increased.

Murray and others (1946), treating patients with streptomycin for infections with Gram-negative bacilli, noted that treatment failures were due to the development of resistance to the drug by the organisms, and they later found that they could produce absolute resistance in vitro by growing the organisms on media containing gradually increasing concentrations of streptomycin. The in vitro resistance developed more rapidly on surface plates than in broth, and some isolated colonies on surface plates sometimes suddenly acquired extreme resistance. This latter phenomenon, it was suggested, might help partially to explain the acquisition of resistance to streptomycin in vivo. Price and others (1947) confirmed that bacterial resistance to streptomycin could be produced rapidly, and to a high degree, both in vitro and in vivo.

Resistance to streptomycin has been shown to be developed, in vitro, by the gonococcus and meningococcus (Miller and Bohnhoff, 1946), and in the case of the gonococcus to develop rapidly requiring only from four to six daily transfers to media containing increasing concentrations of streptomycin in order to become resistant to as much as 75,000 units of streptomycin per $\mathrm{ml}$. of medium. The meningococcus was found to have lost no virulence in the course of developing 
streptomycin-resistance, and one strain appeared to develop enhanced virulence. Increased resistance to penicillin, on the other hand, tended to lower virulence. Organisms becoming resistant to streptomycin showed no cross-resistance, and remained sensitive to penicillin, both in vitro and in vivo.

Ryan (1952) reported the isolation of a streptomycin-resistant strain of gonococcus from a patient who contracted the disease in Hong Kong. Although he thought it unlikely that the resistance developed in vivo during the 3 days that elapsed before making the cultures, this must remain a possibility, since the patient had received $1 \mathrm{~g}$. streptomycin by intramuscular injection at his first visit to the clinic, and a further dose of $1 \mathrm{~g}$. on the second day thereafter, cultures being made on the third day. The strain of $N$. gonorrhoeae isolated grew as well on medium containing $1,000 \mathrm{mg}$. streptomycin per $\mathrm{ml}$. as on a control medium containing no drug.

Streptomycin, Aureomycin, Chloramphenicol, and Terramycin in Gonorrhoea and Non-Specific Urethritis

Although Gocke and others (1950) found experimentally that penicillin, followed by aureomycin, chloramphenicol, terramycin, and streptomycin, in that order, showed the greatest in vitro activity against a number of strains of gonococci, many other authors have declared streptomycin the drug of choice in gonorrhoea complicated by a coincidentally acquired syphilis (Moore, 1949 ; Willcox, 1951 ; Lees, 1951 ; Palazzoli and Delaville, 1951).

Mortara and Saito (1946) reported that eight freshly isolated strains of gonococci were all inhibited in vitro by 5 to 15 units streptomycin per ml. of medium, and it was shown by Buggs and others (1946) that a single intramuscular injection of 500,000 units streptomycin resulted in a serum concentration of between 10 and 15 units at the end of $4 \mathrm{hrs}$.

Favourable results of treatment of acute gonorrhoea in males and females with streptomycin and dihydrostreptomycin have been reported by Chinn and others (1947), Taggart and others (1949, 1950) and Jacoby and others (1950). The effectiveness of streptomycin therapy in urinary tract infections and non-specific urethritis has also been described by Kane and Foley (1947), Adcock and Plumb (1947), Pulaski (1947), and Secrétan (1952).

Aureomycin, chloramphenicol, and terramycin possess greater in vitro activity against the gonococcus than streptomycin (Gocke and others, 1950), and have been shown to be effective in the treat- ment of gonorrhoea (Beinfield and others, 1951 ; Butler and others, 1952; Greaves and others, 1950 ; Robinson, 1950 ; Wright, Metzger, and others, 1951a ; Wright, Prigot, and others, 1951b) and non-specific urethritis (Findlay and Willcox, 1951 ; Thomson, 1951 ; Tissot, 1951; Willcox and Findlay, 1952). All three antibiotics are effective when administered orally, but this advantage is offset by the grave disadvantage of their marked treponemicidal power.

\section{Dosage in Gonorrhoea}

Streptomycin.-A single, intramuscular injection of from 0.3 to $0.5 \mathrm{~g}$. cured all of fifty cases treated by Chinn and others (1947). Single doses of from 0.1 to $0.6 \mathrm{~g}$. were used in 229 cases of gonorrhoea ; 76 (98 per cent.) of the 77 patients given from 0.4 to $0.6 \mathrm{~g}$. were cured (Taggart and others, 1949). Dihydrostreptomycin, in single, intramuscular injections of 0.3 or $0.4 \mathrm{~g}$. cured 71 (92 per cent.) of 77 cases of acute gonorrhoea (Taggart and others, 1950). Jacoby and others (1950) gave 0.5 or $1 \mathrm{~g}$. dihydrostreptomycin to two groups of cases ; sixty (90.9 per cent.) of 66 cases given $0.5 \mathrm{~g}$., and 71 (97.3 per cent.) of 73 cases given $1 \mathrm{~g}$. were cured.

Aureomycin.-Two 500-mg. capsules of aureomycin given by mouth at intervals of 6 hrs, cured sixty $(95 \cdot 2$ per cent.) of 63 gonorrhoea patients treated by Wright and others (1951b). Beinfield and others (1951) gave a total of 1 or $2 \mathrm{gm}$. aureomycin, in divided doses, at either 4- or 6-hourly intervals; 103 (96.3 per cent.) of 107 patients, with an adequate follow-up, were cured. Single oral doses of 1 or $2 \mathrm{~g}$. aureomycin produced an average cure rate of 79 per cent. in 120 cases treated by Robinson and Galen (1951). Collins and others (1949) obtained their best results when $2.5 \mathrm{~g}$. aureomycin or more were given over $36 \mathrm{hrs}$.

Chloramphenicol.-Single doses of 500 or $750 \mathrm{mg}$. chloramphenicol were given orally by Greaves and others (1950) for gonorrhoea; 75 per cent. of sixteen cases given $500 \mathrm{mg}$. and 96 per cent. of fifty cases given $750 \mathrm{mg}$. were cured. Butler and others (1952) found that a single oral dose of $3 \mathrm{~g}$. chloramphenicol (12 capsules) was required to cure all of 103 cases of gonorrhoea, observed for at least $\mathbf{2 3}$ days after treatment; this study was designed to discover the minimum single dose of chloramphenicol which would ensure a 100 per cent cure.

Terramycin.-1 or $2 \mathrm{~g}$. terramycin, in divided doses of 0.25 to $0.5 \mathrm{~g}$. over 6 to $16 \mathrm{hrs}$, cured $164(92.6 \mathrm{per}$ cent.) of 177 cases of gonorrhoea, adequately observed by Wright and others (1951b). The same total dosage (1 or 2 g.), in divided doses 4- or 6-hourly, was used by Beinfield and others (1951); 101 (95.3 per cent.) of 106 cases of gonorrhoea were cured.

Robinson (1950) gave single oral doses of 1 and $2 \mathrm{~g}$. terramycin for acute gonorrhoea. Single $1 \mathrm{~g}$. doses produced only 50 per cent. of cures, and 2-g. doses caused a very high incidence of vomiting; he therefore concluded that single-dose therapy with terramycin was impracticable. 
Dosage in Non-specific Urethritis and Urinary Tract Infections

Streptomycin.-In urinary tract infections, Adcock and Plumb (1947) used streptomycin by intramuscular injection in divided doses to a total of from $2.5 \mathrm{~g}$. over $2 \frac{1}{2}$ days, to $18 \mathrm{~g}$. over 9 days; they reported a high degree of success against infection with the Aerobacter group of organisms, but unsatisfactory results in five cases of infection with Ps. aeruginosa alone or with other organisms, and in one case of infection with E. coli.

Kane and Foley (1947), on the other hand, reported good results in cases of $E$. coli, Ps. aeruginosa, and Proteus vulgaris infection. Using doses of streptomycin as low as $0.5 \mathrm{~g}$. daily for 3 days, they obtained their best results in cases with no evidence of stricture or calculus formation in the urinary tract ; 34 (85 per cent.) of forty patients so treated were cured or improved.

Harkness (1950) suggested that, for non-gonococcal urinary tract infections, streptomycin should be given in divided doses to a-total of from 1 to $3 \mathrm{~g}$. daily for 5 to 7 days.

Aureomycin.-A total dose of $2 \mathrm{~g}$. aureomycin $(250 \mathrm{mg}$. orally every $6 \mathrm{hrs}$ for $48 \mathrm{hrs}$ ) was given by Thomson (1951) in six cases of non-specific urethritis which had proved resistant to either penicillin alone, or to both penicillin and sulphonamide. All six cases are reported as successes, but it was observed that one case required two, and another three such courses before success was achieved. Babione and Graham (1952) claimed that aureomycin gave poor results in the treatment of non-specific urethritis, but failed to mention the doses given.

Chloramphenicol.-Tissot (1951) reported the treatment of seventeen cases of non-specific urethritis of the Waelsch type with chloramphenicol in doses of $0.25 \mathrm{~g}$. by mouth every 3 to 4 hrs for from 4 to 6 days. All seventeen cases were ultimately successful but some only after additional local treatment.

Twelve cases of urethritis, all found to show intracellular virus or pleuropneumonia-like inclusions in urethral scrapings, were treated with chloramphenicol in doses of 0.25 or $0.5 \mathrm{~g}$. 2 to 4 times daily for from 3 to 21 days (Findlay and Willcox, 1951). The total dose varied from 3 to $15.75 \mathrm{~g}$., and success was achieved in eight (66 per cent.).

Terramycin.-Giving divided doses of terramycin over 3 to 20 days to a total of from 3 to $19.25 \mathrm{~g}$. orally, Willcox and Findlay (1952) obtained success in forty (80 per cent.) of fifty cases of non-specific urethritis. A total dose of $5 \mathrm{~g}$. or more was considered to give the best results.

Effect of Streptomycin, Aureomycin, Chloramphenicol, and Terramycin on Treponema pallidum

Streptomycin.-Nichols (1946), Moore (1949), Lees (1951), and Willcox (1951) have claimed that this drug has little treponemicidal effect. Taggart and others (1949) gave a single intramuscular injection of $0.5 \mathrm{~g}$. streptomycin to four patients with dark-field positive syphilitic lesions, and no reduction in the number or activity of the treponemata was seen 6,12 , or $24 \mathrm{hrs}$ later.

Kolmer and others (1946) treated six rabbits with established experimental syphilis with streptomycin in doses totalling from 24,000 units per $\mathrm{kg}$. body-weight up to 240,000 units per $\mathrm{kg}$. over 8 days. In three, some clinical improvement with negative dark-ground examinations was found at the end of 8 days, but all three relapsed, with positive dark-ground examinations, 2 weeks later. The other three rabbits were persistently dark-field positive throughout 10 weeks' observation.

Aureomycin.-Wiggall and others (1949) and Rodriquez and others (1949) reported on the antitreponemal activity of aureomycin given by mouth in divided doses over from 2 to 11 days. The total doses given ranged from 4 to $70 \mathrm{~g}$. and Treponema pallidum was abolished from all lesions in some $48 \mathrm{hrs}$.

Olansky and others (1950) reported that $27 \cdot 3 \mathrm{hrs}$ was the average time taken for the disappearance of treponemata from early syphilitic lesions after doses of from 30 to $240 \mathrm{mg}$. aureomycin daily per $\mathrm{kg}$. bodyweight. It was noted that the larger doses made no significant difference to the time required for darkfield negativity.

Chloramphenicol.-Robinson and others (1949) gave to seventeen patients suffering from early syphilis with dark-field positive lesions $1 \mathrm{~g}$. chloramphenicol every $6 \mathrm{hrs}$, to a total of $40 \mathrm{~g}$.; all became dark-field negative in from 24 to $50 \mathrm{hrs}$ after treatment began.

It was also noted by Greaves and others (1950) that a single dose of $500 \mathrm{mg}$. chloramphenicol (given for acute gonorrhoea) resulted in the disappearance of treponemata from a syphilitic lesion in $48 \mathrm{hrs}$.

Terramycin.-60 mg. per kg. body-weight daily for 8 days was used by Hendricks and others (1950) in the treatment of six cases of early syphilis, all with dark-field positive lesions. Treponema pallidum could not be found 24 to $48 \mathrm{hrs}$ after beginning treatment.

The whole position has been summed up by Robinson (1951). In a survey of the antibiotic treatment of the venereal diseases he reported that streptomycin and dihydrostreptomycin had no effect on the appearance of lesions of early syphilis, even in doses of 20 to $30 \mathrm{~g}$. over 5 to 10 days, whereas aureomycin, chloromycetin, and terramycin might possibly mask syphilis in single oral doses of from 1 to $3 \mathrm{~g}$.

\section{Role of Pleuropneumonia-like Organisms in Urethritis}

Kane and Foley (1947) wrote as follows :

It appears that at least a portion of cases of urethritis that have previously been considered to be non-specific, in the sense that they are non-gono- 
coccal and non-pyogenic in origin, are due to infection by organisms belonging to the pleuropneumonia group.

They described three cases of urethritis in which no organisms, except the pleuropneumonia-like group, could be isolated. All three were treated with streptomycin, from 2 to $4 \mathrm{~g}$. daily for from 8 to 11 days, and the urine was alkalinized. Two uncomplicated cases showed improvement within 3 days of beginning treatment : pleuropneumonia-like organisms disappeared from cultures, and they remained symptom-free over periods of 4 to 6 months' observation. In a case complicated by prostatitis, urethral discharge ceased the day after treatment was begun, but cultures from prostatic secretion and urine continued to grow pleuropneumonia-like organisms during treatment, and urethral discharge re-appeared when streptomycin was stopped.

Edward (1952) quoted Leberman and others (1950), Bushby (1952), and Hatch (1949), as having shown that human genital strains of pleuropneumonia-like organisms were sensitive in vitro to $5 \mu \mathrm{g}$. per $\mathrm{ml}$. streptomycin in most cases, although 15 to $25 \mu \mathrm{g}$. per $\mathrm{ml}$. were required to inhibit a few strains.

Dienes and Smith (1942) produced evidence which tended to support the suggestion that sexual intercourse was a mode of transmission of virulent pleuropneumonia-like organisms, but Nicol produced a greater body of evidence to show that pleuropneumonia-like organisms could be isolated from vaginal cultures in as many instances from virgin as from non-virgin women; that no correlation existed between isolations of pleuropneumonia-like organisms from males suffering from urethritis and isolations from their contacts, and that the isolation of pleuropneumonia-like organisms showed no correlation with the clinical cure of non-specific urethritis (Nicol and Edward, 1953). Edward reported reported that isolations of both anal and genital strains of pleuropneumonia-like organisms were of the same type, and that ninety of 91 isolations, from both healthy and unhealthy subjects were of the same strain. Nicol noted that cultural isolations of pleuropneumonialike organisms bore no relationship to their observation in Geimsa-stained smears.

A number of scrapings from the roof of the anterior urethra from cases of subacute abacterial urethritis have been stained with Geimsa's stain (Harkness, 1950) and examined by myself; no microscopic appearance suggestive of the presence of pleuropneumonia-like organisms was observed.

\section{Discussion and Choice of Therapeutic Substances}

The object of this study was to find a method of treatment which could be applied to urethritis, either gonococcal or non-gonococcal, when the circumstances were such that a microscopic diagnosis prior to treatment was impracticable.
Such a treatment had to satisfy certain criteria :

(i) Ease of Administration.-Any injection technique had to be as simple as that necessary for giving an injection of an aqueous suspension of penicillin.

(ii) Rapidity of Effect.-Urethral discharge should be abolished, and certainly reduced in amount, within the first 24 to $48 \mathrm{hrs}$, in order that both the patient and his attendant should be satisfied with the response to one injection, and would not feel that a second (and perhaps double) dose would be advisable. It appeared likely that such satisfaction would be achieved more certainly if a course of oral therapy, begun at the same time as the initial injection was given, had several days still to run.

(iii) Minimum Toxicity.-Untoward effects of the drug should be avoided as far as possible.

(iv) Avoidance of Masking Syphilis.-The development of a coincidentally acquired syphilis must not be concealed.

That the sulphonamides, per se, were no longer likely to produce satisfactory therapeutic results in gonorrhoea was clear (Dunlop, 1949), but they had been shown to be highly effective in nonspecific urethritis (Babione and Graham, 1952; Secrétan, 1952), and sulphathiazole appeared to possess a relatively wide range of antibacterial activity (Schweinburg and Ruttenburg, 1949). It therefore. appeared reasonable to treat acute gonorrhoea with a highly effective antibiotic, and, at the same time, to give a course of sulphathiazole therapy to combat the residual non-gonococcal urethritis, so often seen to follow acute gonorrhoea, when the gonococci have been eliminated by antibiotic therapy (Harkness, 1950). The reduction of incidence of such residual discharges following combined streptomycin-sulphonamide therapy had been reported by Palazzoli and Delaville (1951). It followed from this that a single antibiotic and sulphonamide combination might perhaps be shown to be effective in both gonococcal and nongonococcal urethritis.

Of the antibiotic substances to be considered (streptomycin, aureomycin, chloramphenicol, and terramycin) streptomycin possessed an immediate advantage over the others in its lack of treponemicidal effect in therapeutically effective doses (Robinson, 1951). Streptomycin also satisfied the first requirement of ease of administration, and it was known that high urinary concentrations of streptomycin were obtained in 3 to $4 \mathrm{hrs}$ after parenteral administration (Keefer and others, 1946 ; Pulaski, 1947).

Both streptomycin and dihydrostreptomycin had been shown to produce high success rates in acute gonorrhoea, by intramuscular or deep subcutaneous 
injection in single doses of the order of $0.5 \mathrm{~g}$. (Chinn and others, 1947 ; Taggart and others, 1949, 1950; Jacoby and others, 1950). Satisfactory results following streptomycin therapy of non-gonococcal urinary tract infections had been reported by Kane and Foley (1947) and Adcock and Plumb (1947), among others.

Bacterial resistance to streptomycin was known to develop rapidly, in vitro and in vivo (Miller and Bohnhoff, 1946; Murray and others, 1946), but it was felt that such an occurrence was unlikely to follow the administration of a single dose of the antibiotic in combination with a sulphonamide, for it had been suggested that combined therapy reduced, and perhaps eliminated, the risk of the development of bacterial resistance (Kimmelman and others, 1951). The combination of streptomycin with a bacteriostatic antibiotic, however, might possibly reduce the bacterial sensitivity to streptomycin (Jawetz, 1952) as well as potentially masking syphilis.

That a synergistic effect resulted from the combination of streptomycin with sulphonamide therapy had been shown (Kolmer and Rule, 1948 ; Garrod, 1953).

A further indication for the addition of oral sulphonamide therapy to streptomycin therapy was the psychological effect of the treatment still having several days to run, if some residual urethral discharge was present for more than $48 \mathrm{hrs}$ after the administration of the streptomycin.

Routine alkalinization of the urine was not undertaken, as it was felt that the possible advantagesincreased effectiveness of the streptomycin (Abraham and Duthie, 1946; Eagle and others, 1951) and reduction of development of bacterial resistance (McDermott, 1948)-were outweighed by the disadvantage of the introduction of an additional complication, bearing in mind the conditions of treatment and the fact that it was intended to use only one dose of antibiotic. Kimmelman and others (1951) had not been able to show any benefit from alkalinization of the urine when combined therapy was used.

Although the weight of evidence seems to point to the fact that pleuropneumonia-like organisms are commensals, it is possible that they may assume virulence under certain conditions. If, then, in some cases they are the cause of urethritis, streptomycin should prove effective in treating this condition (Edward, 1952).

It was decided, therefore, that for the purpose of this study, every patient suffering from urethritis, whether gonococcal or non-gonococcal, should be given a course of combined streptomycin- sulphathiazole therapy. A dose of 1 g. streptomycin or dihydrostreptomycin by deep subcutaneous injection, together with $1.5 \mathrm{~g}$. sulphathiazole by mouth, 4 times daily for 5 days, was chosen, and this treatment was forthwith put to the test, against the remaining criteria of effectiveness and lack of toxicity.

\section{Investigation, Treatment, and Observation}

After a general clinical examination, preparation of urethral smears, inspection of urine, and withdrawal of a specimen of blood for a serological test for syphilis, every patient with urethritis was given $1 \mathrm{~g}$. streptomycin or dihydrostreptomycin by deep subcutaneous injection and three 0.5-g. tablets of sulphathiazole by mouth. An additional 57 sulphathiazole tablets were given to the patient, who was instructed to take three $(1.5 \mathrm{~g}$.), after breakfast, the mid-day meal, and tea, and at bedtime, that is twelve tablets per day $(6 \mathrm{~g}$.). The patient was advised to drink copious fluids, but to avoid alcohol, sexual excitement, and strenuous exercise. He was instructed to report to the clinic $48 \mathrm{hrs}$ later, and to present himself without having passed urine for at least $2 \mathrm{hrs}$ before the examination.

On arrival, the patient's urethra was examined for discharge, and he was then asked to micturate into two urine glasses. Smears having been made of any discharge or urinary shreds found and the findings recorded, the patient was asked to report again on the third day thereafter-the fifth observation day-and to retain his urine for at least $2 \mathrm{hrs}$ before examination.

On the fifth day, a similar examination of the urethra and urine was carried out, and preparations of any urethral discharge or urine shreds were examined microscopically. When the urethra was dry and the urine clear, the patient was asked to return 7 days later. In the absence of urethral discharge or urinary shreds, tests of cure were begun by the intradermal injection of a dose of gonococcal vaccine containing 200 million organisms. The patient was told that alcohol might now be taken, and $48 \mathrm{hrs}$ later, no urethral discharge being found and the urine remaining free of pus or shreds, the largest curved sound admitted by the urethral meatus was passed into the bladder and removed. The seminal vescicles, prostate gland, and Cowper's glands were then massaged per rectum, and specimens of the expressed contents examined microscopically. If no pus cells or gonococci were seen in the exudate, arrangements were made for a final assessment some 24 to $48 \mathrm{hrs}$ 
later, and the patient was then asked to return 3 months later for a clinical and serological examination.

If, at the fifth observation day, any pus shreds remained in the urine, a sample of prostatic secretion was examined for pus and organisms, in the absence of which the treatment consisted of an anterior urethral instillation of silver nitrate solution, in a strength of 0.25 to 0.5 per cent. This was repeated twice weekly, to a maximum of six treatments, but was stopped as soon as the urine became clear of shreds, which frequently happened after only one or two instillations.

A pus haze in the urine was usually treated by twice-daily urethro-vesical irrigation with a 1 in 8,000 solution of oxycyanide of mercury until the condition cleared, and occasionally by further daily injections of $1 \mathrm{~g}$. streptomycin.

Specimens of urethral discharge and prostatic material were examined for the presence of Trichomonas vaginalis, and scrapings were taken from the roof of the anterior urethra in cases of subacute non-gonococcal urethritis to be stained with Geimsa's stain and examined microscopically for the presence of virus and/or pleuropneumonialike intra-cellular inclusion bodies.

A serological test for syphilis was made at the patient's first attendance and again 3 to 6 months later.

Cultural examinations of the urethral discharge were not undertaken as a routine measure. It was felt that the additional expense involved could not be justified by the results likely to be obtained, in view of the experience of Price (1953), who reported on the microscopic and cultural examination of the urethral discharge of 502 male patients over a period of 3 months ; 169 of these patients were found to be suffering from gonorrhoea, smears being positive in 164 cases, cultures in 163. In six cases microscopic examination was positive and cultures negative, and in five cases with positive cultures the smears were negative.

Shortly after the institution of this study, the dose of streptomycin was reduced to $0.5 \mathrm{~g}$. for cases of gonorrhoea, an economy felt to be justifiable where immediate microscopic diagnosis was possible. In one clinic sulphathiazole was used in doses of $4 \mathrm{~g}$. daily for 5 days.

It is of interest to note that indulgence in alcohol was frequently admitted by patients when shreds were found in the urine on the fifth day. Thus even better results would probably be obtained in the case of sailors at sea with no access to alcohol.

\section{Report on Cases Examined}

The report is based on the results obtained with combined streptomycin and sulphathiazole therapy in a total of 540 male cases treated in two clinics during the second half of 1952 and the first 3 months of 1953. Of these cases, 325 were suffering from gonorrhoea, and 215 from non-specific urethritis. Of the latter, 89 cases were diagnosed as bacterial and 126 as abacterial urethritis.

Gonorrhoea.-Of the 325 cases of gonorrhoea treated, 58 patients defaulted or were transferred to other clinics immediately after treatment, 182 were followed-up for a period of 12 days or more after treatment (average 27.7 days), and 85 attended for from 2 to 11 days (Table I).

TABLE I

GONORRHOEA. SUCCESSFUL TREATMENTS

\begin{tabular}{c|c|c|c}
\hline No. of Cases & $\begin{array}{c}\text { Period of } \\
\text { Observation } \\
\text { (days) }\end{array}$ & \multicolumn{2}{|c}{ Successes } \\
\cline { 2 - 4 } & $12+$ & No. & Per cent. \\
\hline 182 & $2-11$ & 169 & $92 \cdot 8$ \\
85 & 0 & - & $97 \cdot 6$ \\
\hline 38 & - & 252 & $95 \cdot 2$ \\
\hline
\end{tabular}

Results. - Of the 182 observed for 12 or more days, 169 (92.8 per cent.) were considered successful, and of the 85 observed for from 2 to 11 days, 83 (97.6 per cent.) were considered successful (Table I).

On the second post-treatment day 246 patients presented themselves for examination; 238 had no urethral discharge (Table II), five were found to have a muco-purulent discharge, two mucus, and one serum from a meatal ulcer (repeatedly dark-field negative) which cleared as the ulcer healed. The two with a mucoid discharge and three of those showing muco-pus defaulted after the second day, and one who still had a muco-purulent discharge and pus shreds in the urine at the fifth day was later re-treated with sulphathiazole and urethro-vesical irrigation.

TABLE II GONORRHOEA. RESULTS ON SECOND AND FIFTH DAY

\begin{tabular}{lr|c|c|c|c}
\hline $\begin{array}{c}\text { Day } \\
\text { after } \\
\text { Treatment }\end{array}$ & $\begin{array}{c}\text { No. of } \\
\text { Patients } \\
\text { Examined }\end{array}$ & $\begin{array}{c}\text { No } \\
\text { Urethral } \\
\text { Discharge }\end{array}$ & $\begin{array}{c}\text { Urine } \\
\text { Clear }\end{array}$ & Percentage \\
\hline Second & $\ldots$ & 246 & 238 & - & $96 \cdot 7$ \\
\hline Fifth & $\ldots$ & 210 & 204 & $-\overline{15}$ & $\begin{array}{c}97 \cdot 1 \\
74 \cdot 7\end{array}$ \\
\hline
\end{tabular}

Of the 210 patients examined on the fifth day after treatment, 204 had no urethral discharge (Table II). Of the six residual discharges, one was frankly purulent, 
four muco-purulent, and one serous (the case of meatal ulcer described above). The purulent discharge resolved without further treatment, as did one of the mucopurulent discharges, but two of these required further antibiotics or chemotherapy, and one local therapy.

Of the 210 examined the urine was clear in 157 (Table II), but 49 contained pus shreds, and four a pus haze. It has already been noted that indulgence in alcohol was frequently admitted by patients who failed to produce a clear urine on the fifth day. Of the 49 with pus shreds in the urine, 36 were observed for 12 days or more and thirteen were transferred to other clinics or defaulted. Of the 36 observed, twenty (55.5 per cent.) achieved a successful outcome without further therapy, ten ( $27 \cdot 7$ per cent.) received additional local treatment only, and six (16.6 per cent.) required further antibiotic treatment or chemotherapy, or are still under observation. Of the four who had a pus haze in the urine at the fifth day, one responded to further chemotherapy, one was re-treated with chloramphenicol, one cleared spontaneously on healing of a meatal ulcer, and the fourth subsequently underwent an operation for the removal of a calculus from the left renal pelvis.

Of the 182 cases which were observed for periods of 12 or more days, 169 were successes (Table I) ; 147 of these ( 86.9 per cent.) were discharged without further treatment of any sort, nineteen ( $11 \cdot 2$ per cent.) received additional local treatment in the form of urethral instillations of 0.25 or 0.5 per cent. silver nitrate and/or urethro-vesical irrigation of mercury oxycyanide $1 / 8,000$ solution. Three $(1.7$ per cent.) were further treated with penicillin for a coincident syphilis.

Dosage.-The dose of streptomycin used was $1.0 \mathrm{~g}$. in 86 cases with 77 successes ( 89.5 per cent.), and $0.5 \mathrm{~g}$. in 96 cases with 82 successes $(85.4$ per cent.). Though the percentage of successes was slightly higher with a $1 \cdot 0$-g. dose, the difference is probably not significant in view of the small numbers involved.

The figures shown in Table III suggest that neither the reduction of the dose of streptomycin from 1.0 to $0.5 \mathrm{~g}$., nor the reduction of total dose of sulphathiazole from 30 to $20 \mathrm{~g}$. over 5 days, produced any significant difference in results.

TABLE III

GONORRHOEA.

COMBINED DOSAGE

\begin{tabular}{|c|c|c|c|c|}
\hline $\begin{array}{l}\text { Streptomycin } \\
\text { Dose (g.) }\end{array}$ & $\begin{array}{l}\text { Sulphathiazole } \\
\text { Total g. over } \\
5 \text { Days }\end{array}$ & $\begin{array}{c}\text { Cases } \\
\text { Treated }\end{array}$ & $\begin{array}{c}\text { Cases } \\
\text { Successful }\end{array}$ & $\begin{array}{l}\text { Percentage } \\
\text { Successes }\end{array}$ \\
\hline 0.5 & $\begin{array}{l}30 \\
20\end{array}$ & $\begin{array}{l:l}79 & 96 \\
17 & 96\end{array}$ & $16 i^{76}$ & $\begin{array}{l}96 \cdot 2 ! \\
94 \cdot 1 i^{85 \cdot 4}\end{array}$ \\
\hline 1.0 & $\begin{array}{l}30 \\
20\end{array}$ & $\begin{array}{l:}18 ! \\
68\end{array}$ & $59 i^{18} 77$ & \begin{tabular}{c|c}
$100 \cdot 0$ & 1 \\
$86 \cdot 7$ & $89 \cdot 5$
\end{tabular} \\
\hline
\end{tabular}

Non-Specific Urethritis.-A total of 215 cases suffering from non-specific urethritis were treated with one injection of $1 \mathrm{~g}$. streptomycin and a 5-day course of sulphathiazole by mouth (either 4 or $6 \mathrm{~g}$. daily). Microscopic examination of urethral smears before treatment had shown 126 of these cases to be abacterial and 89 to be bacterial in origin. Observation for 12 or more days (average 32.2) was carried out in 110 cases, 79 were kept under observation for from 2 to 11 days, and 26 patients were transferred to other clinics or defaulted immediately after treatment (Table IV).

TABLE IV

NON-SPECIFIC URETHRITIS. SUCCESSFUL TREATMENTS

\begin{tabular}{|c|c|c|c|}
\hline \multirow{2}{*}{ No. of Cases } & \multirow{2}{*}{$\begin{array}{c}\text { Period of } \\
\text { Observation } \\
\text { (days) }\end{array}$} & \multicolumn{2}{|c|}{ Successes } \\
\hline & & No. & Percentage \\
\hline $\begin{array}{r}110 \\
79 \\
26\end{array}$ & $\begin{array}{c}12+ \\
2-11 \\
0\end{array}$ & $\begin{array}{l}94 \\
74 \\
- \\
\end{array}$ & $\begin{array}{l}85 \cdot 4 \\
93 \cdot 6 \\
-\end{array}$ \\
\hline 215 & - & 168 & $89 \cdot 5$ \\
\hline
\end{tabular}

Results. - Of the 110 observed for 12 or more days, 94 (85.4 per cent.) were considered successful, and of the 79 observed for from 2 to 11 days, 74 (93.6 per cent.) were considered successful (Table IV).

On the second day after treatment 152 (92.1 per cent.) of the 165 patients who reported for examination had no urethral discharge (Table V), six had a mucoid discharge, and seven a muco-purulent discharge.

TABle V

NON-SPECIFIC URETHRITIS.

RESULTS ON SECOND AND FIFTH DAY

\begin{tabular}{ll|c|c|c|c}
\hline $\begin{array}{c}\text { Day } \\
\text { after } \\
\text { Treatment }\end{array}$ & $\begin{array}{c}\text { No. of } \\
\text { Patients } \\
\text { Examined }\end{array}$ & $\begin{array}{c}\text { No } \\
\text { Urethral } \\
\text { Discharge }\end{array}$ & $\begin{array}{c}\text { Urine } \\
\text { Clear }\end{array}$ & Percentage \\
\hline Second & $\cdots$ & 165 & 152 & - & $92 \cdot 1$ \\
\hline Fifth & $\cdots$ & 143 & 134 & - & $93 \cdot 7$ \\
\hline
\end{tabular}

Six of these thirteen patients with residual urethral discharge were transferred or defaulted immediately after the second day, and of the seven others five had no urethral discharge when seen again on the fifth day, and two had a purulent urethral discharge on the fifth day ; the last two patients were subsequently re-treated with other antibiotics.

Of 143 patients examined on the fifth day after treatment 134 (93.7 per cent.) had no urethral discharge, and in 101 (70.6 per cent.) the urine was clear (Table V). The urethral discharge found on the fifth day was mucoid in two cases, muco-purulent in four, and purulent in three. Five of these patients required further antibiotic treatment or chemotherapy, two local treatment only, and two no further treatment.

Of 34 patients who had pus shreds in the fifth day urine, 26 were observed for 12 or more days and eight defaulted. Of the 26 observed, eleven $(42 \cdot 3$ per cent.) cleared with no further treatment, ten $(38.4$ per cent.) 
cleared with local treatment only, and five (19.2 per cent.) were re-treated with sulphonamides or antibiotics. A pus haze was present in the urine of eight cases, one of whom defaulted, two cleared with local treatment, and five required further antibiotic treatment.

Of the 110 cases which were followed-up for 12 or more days, 94 were successes (Table IV); 76 of these (80.8 per cent.) required no further treatment, and the other eighteen (19.1 per cent.) were given anterior urethral instillations and/or urethro-vesical irrigations.

Dosage.-All the cases of non-specific urethritis were given $1.0 \mathrm{~g}$. streptomycin. Of those observed for 12 or more days, 62 had received a total of $30 \mathrm{~g}$. sulphathiazole over 5 days with 55 successes ( 88.7 per cent.), and 48 a total of $20 \mathrm{~g} ., 39$ successes ( $81 \cdot 2$ per cent.).

While there is an apparent difference of 7.5 per cent. in the success rates, eight of the failures in the group which received the lower dosage of sulphathiazole occurred in complicated cases-three with urethral stricture, two with prostatitis, and one each with Littritis, Cowperitis, and Reiter's syndrome; it is therefore probable that the success rates over a longer series of cases would show rather less difference.

Success Rates.-In Table VI the successes obtained in cases of gonorrhoea and non-specific urethritis which were followed-up for 12 or more days are presented together for comparison. The percentage of successes obtained in cases of bacterial and abacterial urethritis appear to show no significant difference.

TABLE VI

SUCCESS RATES IN GONORRHOEA AND NON-SPECIFIC URETHRITIS

\begin{tabular}{|c|c|c|c|c|c|}
\hline \multicolumn{3}{|c|}{ Type of Case } & $\begin{array}{l}\text { No. Observed } \\
\text { for } 12+\text { Days }\end{array}$ & $\begin{array}{l}\text { Number of } \\
\text { Cases } \\
\text { Successfully } \\
\text { Treated }\end{array}$ & $\begin{array}{l}\text { Percentage } \\
\text { Successes }\end{array}$ \\
\hline \multicolumn{2}{|c|}{ Gonorrhoea } & .. & 182 & 169 & $92 \cdot 8$ \\
\hline \multirow{3}{*}{ 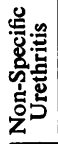 } & Total $\ldots$ & .. & 110 & 94 & $85 \cdot 4$ \\
\hline & Bacterial & .. & 25 & 20 & 80.0 \\
\hline & Abacterial & .. & 85 & 74 & $87 \cdot 0$ \\
\hline
\end{tabular}

Toxicity of Substances Used.-Of the 540 cases treated, 394 were observed for 5 days or more, and only five ( 1.26 per cent.) of the 394 developed toxic signs attributable to sulphathiazole. No toxic effects referable to streptomycin were observed throughout the study.

\section{Summary}

A search has been made for a therapeutic procedure which would achieve success in the treatment of urethritis, both gonococcal and nongonococcal, and at the same time eliminate the risk of masking the development of a coincidentally acquired syphilis. The literature pertaining to the use of the sulphonamide drugs and antibiotics, alone and in combination, in gonococcal and nongonococcal urinary tract infections, and in syphilis is reviewed, and the reasons found therein for the eventual choice of streptomycin and sulphathiazole as therapeutic agents are discussed.

The procedure followed in the investigation, treatment, and observation of cases of urethritis is described in detail. The results of combined streptomycin and sulphathiazole therapy in $\mathbf{5 4 0}$ cases of gonorrhoea and non-specific urethritis are given.

Concurrent combined therapy, consisting of a single deep subcutaneous injection of $1 \mathrm{~g}$. streptomycin, together with $30 \mathrm{~g}$. sulphathiazole in divided doses over 5 days, produced an average cure rate of 90 per cent. in 292 cases of urethritis observed for 12 or more days after initiation of treatment ; 92.8 per cent. of 182 observed cases of gonorrhoea and 85.4 per cent. of 110 observed cases of non-gonococcal urethritis were considered successful.

Urethral discharge was eliminated within $48 \mathrm{hrs}$ of beginning treatment in 238 (96.7 per cent.) of 246 cases of gonorrhoea, and in $152(92.1$ per cent.) of 165 cases of non-specific urethritis examined on the second treatment day.

No toxic effects attributable to streptomycin were observed; those referable to sulphathiazole occurred in only five ( 1.26 per cent.) of 394 cases observed for 5 days or more.

\section{Conclusions}

The injection technique required for the administration of $1 \mathrm{~g}$. streptomycin is no more difficult than that required for the administration of 200,000 units penicillin in aqueous suspension.

A combination of a single 1-g. dose of streptomycin parenterally with concurrent oral sulphathiazole therapy $(1.5 \mathrm{~g}$. four times daily for 5 days) is highly effective in both gonococcal and nongonococcal urethritis.

Urethral discharge is largely eliminated within $48 \mathrm{hrs}$ of the initiation of treatment, and a high rate of cure can be expected.

Although the lack of treponemicidal effect of streptomycin was not demonstrated in this study, the literature shows that it has been well established experimentally.

Where an immediate microscopic diagnosis cannot be made, concurrent combined therapy with streptomycin and sulphathiazole could confidently be recommended for the treatment of urethritis, in preference to penicillin therapy, 
which is ineffective in the treatment of most cases of non-gonococcal urethritis, and carries with it the risk of masking the development of syphilis.

This article is based on a thesis submitted to the University of Aberdeen for the degree of M.D.; permission to publish it has been granted by the Dean of the Faculty of Medicine. My thanks are also due to Dr. A. O. F. Ross, Consultant Adviser in Venereology to the Liverpool Regional Hospital Board, for his help and encouragement.

\section{REFERENCES}

Abraham, E. P., and Duthie, E. S. (1946). Lancet, 1, 455.

Adcock, J. D., and Plumb, R. T. (1947). J. Amer. med. Ass., 133, 579.

Alexander, H. E., Leidy, G., Rake, G., and Donovick, R. (1946). Ibid., 132, 434.

Babione, R. W., and Graham, R. S. (1952). Amer. J. Syph., 36, 480.

Beinfield, M. S., Wright, L. T., DeLuca, F. R., Marmell, M., Metzger, W. I., Whitaker, J. C., and Wilkinson, R. S. (1951). N.Y. St. J. Med., 51, 1054.

Buggs, C. W., Bronstein, B., Hirshfeld, J. W., and Pilling, M. A. (1946). J. Amer. med. Ass., 130, 64.

Bushby, S. R. M. (1952). Personal communication quoted by Edward (1952).

Butler, P. G., Brewer, A. F., Condit, P. K., and Johnston, J. (1952). Amer. J. Syph., 36, 269.

Chinn, B. D., Putnam, L. E., Taggart, S. R., and Herwick, R. P. (1947). Ibid., 31, 268.

Collins, H. S., Trousdale, H., Kaiser, T. F., Regan, F. C., and Finland, M. (1949). Ibid., 33, 263.

Dienes, L., and Smith, W. E. (1942). Proc. Soc. exp. Biol., N.Y., 50. 99.

Dunlop, E. M. C. (1949). British Journal of Venereal Diseases, 25,81 .

Eagle, H., Levy, M., and Fleischman, R. (1952). Antibiot. and Chemother. 2, 563.

Editorial (1952). British Journal of Venereal Diseases, 28, 105.

Edward. D. G. ff. (1952). Ibid., 28, 89.

Findlay, G. M., and Willcox, R. R. (1951). Amer. J. Syph., 35, 583.

Garrod, L. P. (1953). Brit. med. J., 1, 953.

Gocke, T. M., Wilcox, C., and Finland, M. (1950). Amer. J. Syph., 34. 265.

Greaves, A. B., MacDonald, G. R., Romansky, M. J., and Taggart, S. R. (1950). J. vener. Dis. Inform., 31, 261.

Greene, L. F., Weed, L. A., and Albers, D. D. (1952). J. Urol., 67,765 .

Harkness, A. H. (1950). “Non-gonococcal Urethritis." Livingstone, Edinburgh.

Harris, H. W., Murray, R., Paine, T. F., Kilham, L., and Finland, M. (1947). Amer. J. Med., 2, 229.

Hatch, M. H. (1949). "Symposium on Current Progress in the Study of Venereal Diseases," p. 185. U.S. Public Health Service, Washington. Quoted by Edward (1952).

Hendricks, F. D., Greaves, A. B., Olansky, S., Taggart, S. R., Lewis, C. N., Landman, G. S., MacDonald, G. R., and Welch, H. (1950). J. Amer. med. Ass., 143, 4.

Jacoby, A., Goldberg, W., Sobel, N., and Rosenthal, T. (1950). Amer. J. Syph., 34, 185.

Jawetz, E. (1952). Arch. intern. Med., 90, 301.

Kaipainen, W. J. (1951). Ann. Med. exp. Biol. Fenn., 29, Suppl. 1, p. 15.

Kane, L. W., and Foley, G. E. (1947). New. Engl. J. Med., 237, 531.

Keefer, C. S., Blake, F. G., Lockwood, J. S., Long, P. H., Marshall, E. K., Jr., and Wood, W. B. Jr. (1946). J. Amer. med. Ass., 132,4 and 70.
Kimmelman, L. J., Zinsser, H. H., and Klein, M. (1951). J. Urol., $65,668$.

King, A. J. (1939). British Journal of Venereal Diseases, 15, 106.

-(1950). Practitioner, 165, 647.

Kolmer, J. A., and Rule, A. M. (1942). Amer. J. med. Sci., 215, 136. 63, and Paul, A. J. (1946). Proc. Soc. exp. Biol. N.Y. $63,242$.

Leberman, P. R., Smith, P. F., and Morton, H. E. (1950). J. Urol., 64, 167. Quoted by Edward (1952).

Lees, R. (1950). Practitioner, 165, 386.

(1951). British Journal of Venereal Diseases, 27, 34.

Lehr, D. (1945). Proc. Soc. exp. Biol. N.Y., 58, 11.

-(1947). Ibid., 64, 393.

McDermott, W. (1948). Amer. J. Med., 4, 130.

Miller, C. P., and Bohnhoff, M. (1946). J. Amer. med. Ass., 130, 485.

Ministry of War Transport (1946). "The Ship Captain's Medical Guide.” H.M.S.O., London.

Moore, J. E. (1949). British Journal of Venereal Diseases, 25, 169.

Mortara, F., and Saito, M. T. (1946). J. vener. Dis. Inform., 27, 152.

Murray, R., Kilham, L., Wilcox, C., and Finland, M. (1946). Proc. Soc. exp. Biol. N.Y., 63, 470.

Nichols, D. R., and Herrell, W. E. (1946). J. Amer. med. Ass., 132, 200.

Nicol, C. S. (1951). Practitioner, 166, 353.

-, and Edward, D. G. ff. (1953). British Journal of Venereal Diseases, 29, 141.

Nussbaum, S., Goodman, S., Robinson, C., and Ray, L. (1946). J. Pediat., 29, 14.

Olansky, S., Hogan, R. B., Taggart, S. R., Landman, G. S., and Robin, E. D. (1950). Amer. J. Syph., 34, 436.

Palazzoli, M., and Delaville, A. (1951). Presse méd., 59, 7.

Penicillin (Merchant Ships) Act (1951).

Pool, T. L., and Cook, E. N. (1947). J. Amer. med. Ass., 133, 584.

Price, C. W., Randall, W. A., Chandler, V. L., and Reedy, R. J. (1947). J. Bact., 53, 481.

Price, I. N. O., (1953). Personal communication.

Pulasky, E. J. (1947). J. vener. Dis. Inform., 28, 1.

Robinson, H. M. Jr. (1951). Arch' Derm. Syph., Chicago, 64, 284.

Robinson, R. C. V. (1950). Amer. J. Syph., 34, 587.

—, and Galen, W. P. (1951). Ibid., 35, 488.

--, Fox, L. M., and Duvall, R. C. (1949). Ibid., 33, 509.

Rodriquez, J., Plotke, F., Weinstein, S., and Harris, W. W. (1949). J. Amer. med. Ass., 141, 771.

Ross, A. O. F. (1945). British Journal of Venereal Diseases, 21, 123.

Ryan, W. J. (1952). Ibid., 28, 209.

Schatz, A., Bugie, E., and Waksman, S. A. (1944). Proc. Soc. exp. Biol., N.Y., 55, 66.

Schweinburg, F. B., and Rutenburg, A. M. (1949). J. Lab. clin. Med., 34, 1457.

(1950). Proc. Soc.

Secrétan, M. (1952). Schweiz. med. Wschr., 82, 345.

Taggart, S. R., Hirsh, H. L., Hendricks, F. D., Gable, G. R., Puzak, M. A., and Greaves, A. B. (1949). Amer. J. Syph., 33, 177. Putnam, D. E., Greaves, A. B., and Watson, J. A. (1950). Ibid., 34, 62.

Thomson, W. McL. (1951). Med. J. Aust., 1, 149.

Tissot, J. (1951). Progr. méd., Paris, 79, 107.

Weinstein, L., and Murphy, E. B. (1952). Proc. Soc. exp. Biol. N.Y., 80, 519.

Wiggall, R. H., Zheutlin, H. E. C., Trice, E. R., Elmendorf, D. F. Jr., and Robinson, R. C. V. (1949). Amer. J. Syph., 33, 416.

Willcox, R. R. (1951). British Journal of Venereal Diseases, 27, 92.

—, and Findlay, G. M. (1952). Amer. J. Syph., 36, 388.

Wright, L. T., Metzger, W. I., Beinfield, M. S., DiLorenzo, J. C., and Marmell, M. (1951a). Urol. cutan. Rev., 55, 203.

Prigot, A., DiLorenzo, J. C., Whitaker, J. C., and Marmel!, M. (1951b). Amer. J. Syph., 35, 490. 